\title{
Hubungan Perkembangan Nilai Agama dan Moral dengan Perilaku Sosial Anak Usia Dini
}

\author{
Khujatul Khaji ${ }^{1}$, Yuyun Yulianingsih, Teti Ratnasih ${ }^{3}$ \\ 1, 2, ${ }^{3}$ PIAUD FTK UIN Sunan Gunung Djati Bandung \\ Jalan Soekarno-Hatta Kel. Cimincrang, Gedebage Kota Bandung, Jawa Barat, Indonesia \\ Email:khujatulkhaji97@gmail.com¹,yuyunyulianingsih67@gmail.com², \\ tetiratnasih@gmail.com
}

Naskah diterima: 29 November 2019, direvisi: 17 Februari 2020, diterbitkan: 31 Maret 2020

\begin{abstract}
Abstrak
Penelitian ini membahas tentang hubungan perkembangan nilai agama dan moral dengan perilaku sosial anak usia dini kelompok B RA PERSIS 235 Nasrullah Ujungberung Bandung. Penelitian ini menggunakan pendekatan kuantitatif dengan metode deskriptif analitik yang menggunakan teknik korelasi. Subjek dalam penelitian ini adalah anak kelompok B RA PERSIS 235 Nasrullah Ujung Berung Bandung Tahun Pelajaran 2018/2019 yang berjumlah 28 anak. Teknik pengumpulan data yang digunakan yaitu observasi, wawancara dan dokumentasi. Hasil penelitian menunjukkan perkembangan nilai agama dan moral anak kelompok B RA PERSIS 235 Nasrullah Ujungberung Bandung berada pada kategori tinggi dengan perolehan nilai sebesar 3,77 yang berada pada interval 3,40 - 4,19. Perilaku sosial anak kelompok B RA PERSIS 235 Nasrullah Ujungberung Bandung berada pada kategori tinggi dengan perolehan nilai sebesar 3,5 yang berada pada interval 3,40 - 4,19. Hubungan antara perkembangan nilai agama dan moral dengan perilaku sosial anak kelompok B RA PERSIS 235 Nasrullah Ujungberung Bandung diperoleh angka koefisien korelasi sebesar 0,83. Berdasarkan hasil tersebut dapat disimpulkan bahwa terdapat hubungan yang positif dan signifikan antara perkembangan nilai agama dan moral dengan perilaku sosial anak usia dini di kelompok B RA PERSIS 235 Nasrullah Ujungberung Bandung dengan tingkat hubungan yang sangat tinggi karena berada pada interval koefisien korelasi $0,800-\mathbf{1}, 000$.
\end{abstract}

Kata kunci: anak usia dini, perkembangan nilai agama dan moral, perilaku sosia 


\begin{abstract}
This study discusses the relationship between the development of religious and moral values with the social behavior of early childhood groups B RA PERSIS 235 Nasrullah Ujungberung Bandung. This research uses a quantitative approach with descriptive analytic methods that use correlation techniques. The subjects in this study were children of group B RA PERSIS 235 Nasrullah Ujung Berung Bandung in 2018/2019 Academic Year totaling 28 children. Data collection techniques used are observation, interviews and documentation. The results showed the development of religious and moral values of children of group B RA PERSIS 235 Nasrullah Ujungberung Bandung were in the high category with the acquisition of a value of 3.77 which was at an interval of 3.40 - 4.19. Social behavior of B RA PERSIS 235 Nasrullah Ujungberung Bandung children is in the high category with the acquisition of a value of 3.5 which is in the interval from 3.40 to 4.19. The relationship between the development of religious and moral values and social behavior of children of group B RA PERSIS 235 Nasrullah Ujungberung Bandung obtained a correlation coefficient of 0.83 . Based on these results it can be concluded that there is a positive and significant relationship between the development of religious and moral values with social behavior of young children of group B RA PERSIS 235 Nasrullah Ujungberung Bandung with a very high level of relationship because it is in the interval of the correlation coefficient from 0.800 to 1,000.
\end{abstract}

Keywords: early childhood, the development of religious and moral values, social behavior

\title{
Pendahuluan
}

Menurut National Association for The Education of Young Childern (NAEYC) anak usia dini adalah anak yang mendapatkan layanan pendidikan dalam keluarga, pendidikan prasekolah baik negeri maupun swasta, taman kanak-kanak maupun sekolah dasar yang berada dalam rentang usia 0-8 tahun. Usia dini merupakan periode awal yang paling penting dan mendasar dalam sepanjang rentang pertumbuhan serta perkembangan kehidupan manusia. Masa usia dini adalah the golden ages atau masa keemasan. Pada masa ini anak mengalami pematangan fungsi-fungsi fisik dan psikis yang siap merespon stimulasi yang diberikan oleh lingkungan. Menurut Montessori (Sujiono, 2013:54) masa usia dini merupakan masa sensitif, yaitu masa anak mudah menerima stimulus dari lingkungannya. Masa ini merupakan masa untuk mengembangkan potensi yang dimiliki anak. Potensi tersebut dapat dikembangkan melalui pendidikan. 
Menurut UU RI No. 20 tahun 2003 tentang Sistem Pendidikan Nasional pasal 1 ayat 1 pendidikan merupakan usaha sadar dan terencana untuk mewujudkan suasana belajar dan proses pembelajaran agar peserta didik secara aktif mengembangkan potensi dirinya untuk memiliki kekuatan spiritual keagamaan, pengendalian diri, kepribadian, kecerdasan, akhlak mulia serta keterampilan yang diperlukan dirinya, masyarakat, bangsa dan negara (Sisdiknas, 2003:6).

Perubahan paradigma dalam bidang pendidikan dan berbagai perkembangan dalam ilmu pengetahuan, teknologi dan seni membawa implikasi terhadap berbagai aspek pendidikan, termasuk pada kebijakan pendidikan. Seiring waktu, perhatian pemerintah mulai tertuju pada pendidikan sebelum jenjang pendidikan dasar, yaitu pendidikan anak usia dini (PAUD). Pendidikan anak usia dini (early childhood education) merupakan suatu disiplin ilmu pendidikan yang secara khusus memperhatikan, menelaah, dan mengembangkan berbagai interaksi edukatif antara anak usia dini dengan pendidik untuk mencapai pertumbuhan dan perkembangan potensi anak secara optimal (Nurtanfidiyah, 2018:4).

Pendidikan Anak Usia Dini (PAUD) merupakan lembaga yang sangat penting untuk diikuti guna mewujudkan generasi penerus bangsa yang berkualitas. Lembaga PAUD menitikberatkan pada peletakan dasar ke arah pertumbuhan dan perkembangan nilai agama dan moral, kognitif, fisik motorik, sosial emosional, bahasa dan seni sesuai dengan keunikan dan tahap-tahap perkembangan yang dilalui anak (Hasyim, 2015:217).

Salah satu aspek yang harus dikembangakan pada anak usia dini yaitu aspek perkembangan nilai agama dan moral. Perkembangan nilai agama pada anak usia dini mempunyai peran yang sangat penting. Penanaman nilai-nilai agama menyangkut konsep ketuhanan, ibadah, nilai moral yang berlangsung sejak dini mampu membentuk religiulitas anak mengakar secara kuat dan mempunyai pengaruh sepanjang hidup (Latif, 2013:152).

Menurut John W. Santrock (2007:117) perkembangan nilai agama dan moral adalah pemahaman manusia terhadap benar dan salah yang didasarkan pada penalaran dan perasaan. Perkembangan nilai agama dan moral dapat dijadikan sebagai pondasi yang kokoh dan sangat penting keberadaannya. Perkembangan nilai agama dan moral merupakan awal yang baik bagi pendidikan anak bangsa.

Menurut Suyadi (2009:25) perkembangan nilai agama dan moral adalah pedoman seseorang sebagai warga negara dan warga masyarakat dalam bertingkah laku. Berkembangnya nilai agama dan moral dapat mempengaruhi pengetahuan dan pemahaman seseorang terhadap perbuatan maupun perkataan yang baik dan tidak baik. Oleh karena itu 
pendidikan pada anak usia dini harus berprinsip pada perkembangan nilai agama dan moral sebagai upaya untuk mengantarkan anak menuju kedewasaan berpikir, bersikap dan berperilaku secara terpuji sesuai dengan syariat agama dan norma yang berlaku pada masyarakat.

Menurut Carolyn Meggit (2013:16) cakupan dalam perkembangan nilai agama dan moral yaitu berkenaan dengan pengembangan kesadaran untuk membina hubungan dengan orang lain secara etis, bermoral dan manusiawi. Di dalamnya termasuk pula pemahaman akan nilai-nilai (seperti nilai kejujuran dan hormat) serta pemahaman akan konsep lain seperti konsep benar dan salah serta konsep konsekuensi dan tanggung jawab.

Perkembangan nilai agama dan moral erat kaitannya dengan perilaku sosial seorang anak, sikap sopan santun, kemauan melaksanakan ajaran agama dalam kehidupan seharihari. Dengan nilai agama dan moral yang dimiliki seorang anak diharapkan dapat membedakan perilaku baik dan buruk, taat dalam menjalankan perintah agama dalam kehidupan serta dapat memiliki perilaku sosial yang sesuai dengan nilai agama dan moral. Dengan kata lain, apabila perkembangan nilai agama dan moralnya baik maka perilaku sosialnya pun akan baik.

Perilaku sosial anak usia dini menurut Beaty (Faridatul, 2015:59) adalah perilaku yang mencerminkan kepedulian atau perhatian dari seorang anak ke anak lainnya, misalnya membantu, menghibur, atau hanya tersenyum pada anak lain. Perilaku sosial dipengaruhi oleh berbagai faktor seperti faktor lingkungan. Lingkungan di mana individu itu berada merupakan faktor yang paling dominan. Menjadi pribadi yang sosial tidak dapat dipelajari dalam waktu singkat. Perilaku sosial diperoleh anak melalui kematangan dan kesempatan belajar dari berbagai stimulus yang diberikan lingkungannya.

Berdasarkan observasi pendahuluan yang dilakukan oleh peneliti di RA PERSIS 235 Nasrullah Ujungberung Bandung ditemukan fakta bahwa RA Persis 235 Nasrullah Ujung Berung Bandung adalah suatu lembaga pendidikan dan pengajaran anak-anak yang menjadikan pendidikan agama Islam sebagai identitas lembaganya. Para pendidik sangat menjunjung tinggi nilai agama dan moral anak. Hal ini dibuktikan dengan realitas perkembangan nilai agama dan moral anak yang sudang berkembang dengan baik. Namun pada kenyataannya, berkembangnya nilai agama dan moral tidak sejalan dengan perilaku sosial anak kelompok B RA PERSIS 235 Ujungberung Bandung. Dari 28 anak, terdapat 10 anak yang perkembangan nilai agama dan moralnya berkembang dengan baik namun perilaku sosialnya belum berkembang dengan baik. 
Berdasarkan latar belakang masalah tersebut, terdapat beberapa rumusan masalah yang bertujuan untuk mengetahui: (1) realitas perkembangan nilai agama dan moral anak kelompok B RA PERSIS 235 Nasrullah Ujungberung Bandung (2) realitas perilaku sosial anak kelompok B RA PERSIS 235 Nasrullah Ujungberung Bandung (3) realitas hubungan perkembangan nilai agama dan moral dengan perilaku sosial anak kelompok B RA PERSIS 235 Nasrullah Ujungberung Bandung.

\section{Metodologi}

Penelitian ini menggunakan metode diskriptif analitik dengan pendekatan kuantitatif yang menggunakan teknik korelasi. Metode deskriptif merupakan metode yang diarahkan untuk memecahkan masalah dengan cara memaparkan atau menggambarkan apa adanya (Sudjana, 2009:7). Menurut Subana dan Sudrajat (2011:26-27) penelitian deskriptif menuturkan dan menafsirkan data yang berkenaan dengan situasi yang terjadi dan dialami sekarang, sikap dan pandangan yang menggejala saat sekarang, hubungan antar variabel, pertentangan dua kondisi atau lebih, pengaruh terhadap suatu kondisi, perbedaanperbedaan antar fakta. Penelitian ini bermaksud untuk mendeskripsikan hubungan antara perkembangan nilai agama dan moral dengan perilaku sosial dengan cara mengambil data yang berhubungan dengan variabel tersebut, kemudian data yang sudah diperoleh akan diolah dan dianalisis sehingga menghasilkan sebuah kesimpulan.

Teknik penelitian yang digunakan dalam penelitian ini adalah teknik korelasional. Menurut Sugiyono (2011:87) teknik korelasi adalah teknik penelitian yang berusaha menghubungkan antara satu unsur/elemen dengan unsur/elemen lain untuk menciptakan bentuk dan wujud baru yang berbeda dengan sebelumnya. Teknik ini dilakukan dengan cara mengumpulkan, mengolah, menganalisis dan menginterpretasikan data yang berhubungan dengan perkembangan nilai agama dan moral dan perilaku sosial anak usia dini.

Teknik pengumpulan data dalam penelitian ini meliputi observasi, wawancara dan dokumentasi. Observasi yaitu teknik pengumpulan data yang dilakukan dengan cara pengamatan pada kegiatan yang sedang berlangsung. Observasi yang digunakan untuk mengamati perkembangan nilai agama dan moral dan perilaku sosial anak di Kelompok B RA PERSIS 235 Nasrullah Ujungberung Bandung. Wawancara merupakan sebuah alat pengumpul informasi dengan sejumlah pertanyaan secara lisan (Sukmadinata, 2005). Wawancara dalam penelitian ini dilakukan secara langsung terhadap guru kelas B RA PERSIS 235 Nasrullah Ujungberung Bandung untuk mendapatkan informasi yang lebih 
jelas tentang perkembangan nilai agama dan moral serta perilaku sosial anak. Jenis wawancara dalam penelitian ini yaitu wawancara tidak terstruktur. Wawancara tidak terstruktur yaitu jenis wawancara yang bebas, peneliti tidak menggunakan pedoman wawancara yang telah tersusun secara sistematis dan lengkap untuk pengumpulan datanya. Dokumentasi yaitu mencari data mengenai hal-hal atau variabel yang berupa catatan, transkip, buku, surat kabar, majalah, prasasti, notulen rapat, lengger, agenda dan sebagainya (Arikunto, 2010:274). Dokumentasi digunakan oleh peneliti untuk mendapatkan data-data yang bersifat dokumenter dari sekolah berupa foto, vidio dan arsip-arsip.

Sedangkan analisis data dalam penelitian ini menggunakan teknik statistik dengan tahapan (1) uji validitas, yaitu suatu ukuran yang menunjukkan tingkat kevalidan suatu instrumen (2) uji persyaratan analisa, termasuk di dalamnya uji normalitas dan uji regresi (3) uji analisis hasil penelitian, termasuk di dalamnya analisis parsial yaitu teknik analisis yang digunakan untuk menguji dan menghitung variabel $\mathrm{X}$ dan variabel $\mathrm{Y}$ secara terpisah dan analisis korelasi yaitu untuk mengetahui signifikansi hubungan antara variabel $\mathrm{X}$ dengan variabel Y dengan menggunakan rumus korelasi product moment dengan rumus:

$$
r_{x y}=\frac{N \cdot \sum \mathrm{XY}-\left(\sum \mathrm{X}\right)\left(\sum \mathrm{Y}\right)}{\sqrt{\left\{N \sum \mathrm{X}^{2}-\left(\sum \mathrm{X}\right)^{2}\right\}\left\{N \sum \mathrm{Y}^{2}-\left(\sum \mathrm{Y}\right)^{2}\right.}}
$$

(Hayati, 2013: 94)

\section{Hasil dan Diskusi}

\section{Perkembangan Nilai Agama dan Moral}

Untuk mengetahui realitas perkembangan nilai agama dan moral anak usia dini di kelompok B kelompok B RA PERSIS 235 Ujungberung Bandung diperoleh empat indikator yang berdasarkan pada Standar Tingkat Pencapaian Perkembangan Anak (STTPA) usia 5-6 Tahun yang terdapat dalam Kurikulum 2013, yaitu: (1) mengenal agama yang dianut (2) mengerjakan ibadah (3) Berperilaku jujur, penolong, sopan, hormat, sportif (4) Menjaga kebersihan diri dan lingkungan. Kemudian dari empat indikator tersebut diperoleh pernyataan observasi sebanyak 10 item dan akan dianalisis setiap item perindikatornya. Skala penilaian mengacu pada pedoman penilaian PAUD dari Direktorat Pembinaan Pendidikan Anak Usia Dini, setiap penilaian belum berkembang diberi skor 1, 
mulai berkembang diberi skor 2, berkembang sesuai harapan diberi skor 3 dan berkembang sangat baik diberi skor 4 .

Setelah diketahui nilai rata-rata setiap variabel kemudian diinterpretasikan pada skala lima absolut sebagai berikut: (1) 1,00 - 1,79 berarti sangat rendah (2) 1,80 - 2,59 berarti rendah (3) 2,60 - 3,39 berarti sedang (4) 3,40 - 4,19 berarti tinggi (5) 4,20 - 5,00 berarti sangat tinggi (Syah, 2010:151).

Berdasarkan hasil perhitungan, diperoleh data sebagai berikut:

Tabel 1. Analisis Perindikator Variabel X

\begin{tabular}{|c|l|c|c|c|}
\hline No. & \multicolumn{1}{|c|}{ Indikator } & Rata-rata & Interval & Kategori \\
\hline 1. & Mengenal agama yang dianut & 2,69 & $2,60-3,39$ & Sedang \\
\hline 2. & Mengerjakan ibadah & 3,12 & $2,60-3,39$ & Sedang \\
\hline 3. & $\begin{array}{l}\text { Berperilaku jujur, penolong, } \\
\text { hormat, sopan, sportif }\end{array}$ & 3,03 & $2,60-3,39$ & Sedang \\
\hline 4. & $\begin{array}{l}\text { Menjaga kebersihan diri dan } \\
\text { lingkungan }\end{array}$ & 3,26 & $2,60-3,39$ & Sedang \\
\hline \multicolumn{2}{|l|}{ Rata-rata seluruh indicator } & 3,77 & $3,40-4,19$ & Tinggi \\
\hline
\end{tabular}

Berdasarkan hasil perhitungan, diperoleh rata-rata indikator Variabel $\mathrm{X}$ (perkembangan nilai agama dan moral) adalah $(2,69+3,12+3,03+3,26): 4=1,21: 4=$ 3,02. Kemudian hasil tersebut dikonversi ke dalam skala lima absolute $\frac{3,02}{4} \times 5=3,77$. Dengan demikian, perkembangan nilai agama dan moral pada anak kelompok B RA PERSIS 235 Nasrullah Ujungberung Bandung termasuk pada kategori tinggi karena berada pada interval 3,40 - 4,19.

Sementara itu, berdasarkan hasil perhitungan chi kuadrat pada taraf signifikansi $5 \%$ dan $\mathrm{db}=5$, diperoleh perhitungan $x^{2}$ hitung $=3,37$ dan $x^{2}$ tabel $=11,070$. Maka dengan demikian $x^{2}$ hitung $<x^{2}$ artinya data variabel $\mathrm{X}$ (perkembangan nilai agama dan moral) berdistribusi normal. 


\section{Perilaku Sosial}

Untuk mengetahui realitas perilaku sosial anak usia dini di kelompok B kelompok B RA PERSIS 235 Ujungberung Bandung diperoleh empat indikator, yaitu: (1) hasrat akan penerimaan sosial (2) ketergantungan (3) kemurahan hati (4) kerjasama (Hurlock, 2007:262). Kemudian dari empat indikator tersebut diperoleh pernyataan observasi sebanyak 11 item dan akan dianalisa setiap item perindikatornya. Skala penilaian mengacu pada pedoman penilaian PAUD dari Direktorat Pembinaan Pendidikan Anak Usia Dini, setiap penilaian belum berkembang diberi skor 1, mulai berkembang diberi skor 2 , berkembang sesuai harapan diberi skor 3 dan berkembang sangat baik diberi skor 4 .

Tabel 2. Analisis Perindikator Variabel Y

\begin{tabular}{|c|l|c|c|c|}
\hline No. & \multicolumn{1}{|c|}{ Indikator } & Rata-rata & Interval & Kategori \\
\hline 1. & $\begin{array}{l}\text { Hasrat akan penerimaan } \\
\text { sosial }\end{array}$ & 2,52 & $1,80-2,59$ & Rendah \\
\hline 2. & Ketergantungan & 2,64 & $2,60-3,39$ & Sedang \\
\hline 3. & Kemurahan hati & 3,15 & $2,60-3,39$ & Sedang \\
\hline 4. & Kerjasama & 2,91 & $2,60-3,39$ & Sedang \\
\hline \multicolumn{2}{|r|}{ Rata-rata seluruh indikator } & 3,5 & $3,40-4,19$ & Tinggi \\
\hline
\end{tabular}

Berdasarkan hasil perhitungan, diperoleh rata-rata indikator variabel Y yaitu $(2,52+$ $2,64+3,15+2,91): 4=11,22: 4=2,80$. Kemudian hasil tersebut dikonversi ke dalam skala lima absolut $\frac{2,80}{4} \times 5=3,5$. Dengan demikian, perilaku sosial kelompok B RA PERSIS 235 Nasrullah Ujungberung Bandung termasuk pada kategori tinggi karena berada pada interval 3,40 - 4,19.

Sementara itu, berdasarkan hasil perhitungan chi kuadrat pada taraf signifikansi $5 \%$ dan $\mathrm{db}=5$, diperoleh perhitungan $x^{2}$ hitung $=4,57$ dan $x^{2}$ tabel $=11,070$. Maka dengan demikian $x^{2}$ hitung $<x^{2}$ artinya data variabel $\mathrm{Y}$ (perilaku sosial) berdistribusi normal.

Berdasarkan hasil observasi sebagian besar responden memiliki perilaku sosial yang baik, namun ada beberapa yang belum maksimal. Hal ini terjadi karena dalam berperilaku 
sosial anak cenderung meniru lingkungan sekitarnya, baik lingkungan sekolah, keluarga maupun masyarakat. Oleh karena itu, ketiga komponen tersebut harus sejalan dalam memberikan stimulus dan tauladan pada anak. Ketika anak melihat semua orang di lingkungannya berperilaku baik maka secara otomatis anak akan mengikutinya. Begitupun sebaliknya, apabila anak melihat ada orang yang berperilaku kurang baik, maka anak akan mengikutinya.

\section{Hubungan Perkembangan Nilai Agama dan Moral dengan Perilaku Sosial Anak Usia Dini}

Berdasarkan haisl analisis diketahui bahwa data kedua variabel berdistribusi normal dan regresinya linier. Oleh karena itu analisis hubungan variabel $\mathrm{X}$ dengan variabel $\mathrm{Y}$ ditentukan dengan menggunakan rumus Product Moment.

Berdasarkan hasil perhitungan diperoleh harga koefisien korelasi sebesar 0,83. Dengan demikian, dapat diinterpretasikan bahwa hubungan antara variabel $\mathrm{X}$ dengan variabel $\mathrm{Y}$ tergolong pada kategori sangat tinggi karena berada pada interval koefisien korelasi 0,800-1,000.

Hasil pengujian hipotesis, diperoleh harga $\mathrm{t}$ hitung $=7,53$ dan $\mathrm{t}$ tabel $=2,06$. Berarti $\mathrm{t}$ hitung lebih besar dari $\mathrm{t}$ tabel $\left(\mathrm{t}_{\text {hitung }} 7,53>\mathrm{t}_{\text {tabel }}\right.$ 2,06). Dalam keadaan demikian maka hipotesis nol $(\mathrm{H} 0)$ ditolak, sedangkan hipotesis alternatif $(\mathrm{Ha})$ diterima. Dengan kata lain, ada hubungan yang positif dan signifikan antara perkembangan nilai agama dan moral dengan perilaku sosial anak kelompok B RA PERSIS 235 Nasrullah Ujungberung Bandung.

Hasil perhitungan tersebut membuktikan bahwa ada hubungan yang positif dan signifikan antara perkembangan nilai agama dan moral dengan perilaku sosial anak. Hal ini sesuai dengan pendapat Kohlberg (Mansur, 2014) yang menyatakan bahwa perkembangan nilai agama dan moral pada anak usia 5-6 tahun merupakan suatu kemampuan untuk berinteraksi dengan tingkah laku yang baik sesuai dengan norma-norma, sehingga menimbulkan perilaku yang baik dan buruk.. Berdasarkan pernyataan tersebut, dapat dipahami bahwa perkembangan nilai agama dan moral memuat tentang perilaku anak baik perilaku terhadap Allah SWT, perilaku terhadap sesama manusia maupun perilaku terhadap lingkungan. Dengan kata lain perilaku sosial merupakan wujud nyata dari perkembangan nilai agama dan moral.

Hal ini diperkuat juga oleh pendapat Hurlock (2007) yang menyatakan bahwa perkembangan nilai agama dan moral mencakup tentang perkembangan fikiran (kognitif), 
perasaan dan perilaku menurut aturan atau kebiasaan mengenai hal-hal yang seharusnya dilakukan seseorang ketika berinteraksi dengan orang lain. Hal ini menunjukkan bahwa perilaku sosial merupakan bagian dari perkembangan nilai agama dan moral anak usia dini. Artinya baik atau buruk perkembangna nilai agama dan moral seorang anak akan berpengaruh pada perilaku sosial anak. Untuk itu, nilai agama dan moral harus tertanam dan terpatri dengan baik dalam setiap insan sejak dini, hal tersebut merupakan awal yang baik bagi pendidikan anak bangsa untuk menjalani pendidikan selanjutnya.

\section{Penutup}

Berdasarkan hasil perhitungan dapat disimpulkan bahwa terdapat hubungan yang positif dan signifikan antara perkembangan nilai agama dan moral dengan perilaku sosial anak usia dini di RA PERSIS 235 Nasrullah Ujungberung Bandung dengan rincian perolehan nilai sebagai berikut: (1) Perkembangan nilai agama dan moral anak kelompok B RA PERSIS 235 Nasrullah Ujungberung Bandung berada pada kategori tinggi yang ditandai dengan perolehan nilai rata-rata seluruh indikator sebesar 3,77 yang berada pada interval 3,40 - 4,19 (2) Perilaku sosial anak kelompok B RA PERSIS 235 Nasrullah Ujungberung Bandung berada pada kategori tinggi ditandai dengan perolehan nilai rata-rata seluruh indikator sebesar 3,5 yang berada pada interval 3,40 - 4,19 (3) Hubungan antara perkembangan nilai agama dan moral dengan perilaku sosial kelompok B RA PERSIS 235 Nasrullah Ujungberung Bandung berada pada kategori yang sangat tinggi yang ditandai dengan koefisien korelasi sebesar 0,83 yang berada pada interval koefisien korelasi $0,800-1,000$.

Berdasarkan hasil penelitian yang dilakukan, ada beberapa saran yang dapat menjadi bahan pertimbangan bagi pihak yang bersangkutan, antara lain: (1) Pendidik sebaiknya selalu berfikir kreatif dan inovatif dalam menciptakan pembelajaran yang baik dan menyenangkan bagi peserta didik sehingga peserta didik lebih mudah dalam menerima rangsangan atau stimulus yang diberikan. (2) Hendaknya pendidik dan orangtua bekerjasama dan berkoordinasi dalam proses pembelajaran sehingga anak dapat berkembang dengan optimal. (3) Penelitian ini dilaksanakan pada objek dan populasi penelitian yang terbatas. Untuk itu dipersilahkan bagi peneliti lain untuk melakukan penelitian ulang atau lanjutan yang melibatkan objek dan populasi penelitian yang lebih luas. 


\section{Daftar Pustaka}

Arikunto, S. (2010). Prosedur Penelitian (Suatu Pendekatan Praktik). Jakarta: Rineka Cipta.

Direktorat Pembinaan Pendidikan Anak Usia Dini. (2015). Pedoman Penilaian Pembelajaran Pendidikan Anak Usia Dini. Jakarta

Faridatul, Lina M. K. (2015). Analisis Kemampuan Sosial Anak. https://journal.upgris.ac.id/index.php/paudia/article/view/2014 Diakses pada tanggal 20 November 2018

Hasyim, S. L. (2015). Pendidikan Anak Usia Dini dalam Perspektif Islam. Jurnal Lentera, $217-$ 218.

Hayati, Tuti. (2014). Pengantar Statistika Pendidikan. Bandung: CV Insan Mandiri.

Hurlock, B. Elizabeth. (2007). Perkembangan Anak. (Meitasari Tjandrasa, \& Muslichah Zarkasih, Pennerjemah.). Jakarrta: Erlangga.

Latif, Mukhtar, d. (2013). Orientasi Baru Pendidikan Anak Usia Dini. Jakarta: Kencana Prenada Media Group.

Mansur. (2014). PAUD dalam Islam. Yogyakarta: Pustaka Pelajar.

Meggittt, C. (2013). Memahami Perkennbangan Anak. Jakartia: PT Indeks.

Nurtanfidiyah. (2018). Perkambangan Agama Dan Moral Yang Tidak Tercapai. Jurnal $\begin{array}{lllll}\text { Pendidikan } & \text { Anak, } & \text { Vol. } & 4 & \text { No. }\end{array}$ https://journal.walisongo.ac.id/index.php/Nadwa/article/view/1810/pdf_1

Diakses pada tanggal 03 Januari 2019

Santrock, W. John. (2007). Perkembangan Anak (Mila Rachmawati \& Anna Kuswanti, Penerjemah.). Jakarta: Erlangga.

Standar Tingkat Pencapaian Perkembangan Anak (STTPA) usia 5-6 Tahun yang terdapat dalam Kurikulum 2013.

Subana, M., Sudrajat. (2011). Dasar-Dasar Penelitian Ilmiah, Bandung: Pustaka Setia.

Sudjana, N. (2009). Penilaian Hasil Proses Belajar Mengajar. Bandung: PT Remaja Rosdakarya.

Sugiyono. (2011). Statistika untuk Penelitian. Bandung: Alfabeta.

Sujiono, Y. N. (2013). Konsep Dasar Pendidikan Anak Usia Dini. Jakarta: PT. Indeks.

Sukmadinata, N. S. (2005). Metode Penelitian Pendidikan. Bandung: Remaja Rosdakarya.

Syah, M. (2010). Psikologi Pendidikan dengan Pendekatan Baru. Bandung: PT Remaja Rosdakarya. 